\title{
Words for Miriam
}

\author{
Sandra Haar
}

\section{Quelques mots pour Miriam}

Je n'arrivais pas à détacher mes yeux d'elle Je revenais sans cesse une photographie dans un cadre exposée 100 ans de Yiddish au Canada spectacle déplaisant (Quelqu'un a-t-il vu ce que j'ai vu?) attirant comme le désir comme une identification me fixant une femme dans une photographie... yeux intelligents et espiègles une badkn femelle habillée comme un homme vêtue d'un habit d'homme foncé une jeune femme sur un chemin de terre s'estompant dans la distance le dos voûté avec un sourire satisfait habillée comme un homme....

I couldn't take my eyes off her I kept returning a photograph in a case on exhibit 100 years of Yiddish in Canada an unlikely spectacle (did anyone see what I saw?) drawn in like desire like identification staring out at me a woman in a photograph almost before photographs were made in the basement room from 'round back down the passageway a large synagogue on Bathurst Street

how far is that? how long ago to almost before photographs to return again to her to an exhibit case with the inscription a female badkn dressed as a man

clever and mischievous eyes a female badkn clad in a man's dark suit a young woman on dirt road blurring into the distance hunching her back over smirking dressed as a man (how long ago?) edges of the paper curling (how far away?) a female badkn dressed as a man clever and mischievous beard affixed to her face

Miriam Mirtenbaum pleased to meet you 
i have some questions who to ask call the synagogue damn! after hours call the next day just before closing oh! i'll connect you to the curator what's the extensionagain? leavea message ok call back four days later the curator will pass on my number to a man whose family took the photograph i wait five weeks nocall i call her back the curator oh! she forgot so many things to do and she is on her way out now here is someone else would you give this woman the address sure well his phone number and here i see his address

now five weeks later i haven't written haven't called

how far is it to the telephone or is the distance between the cluster of brain molecules that types this poem and my fingers shorter than those that type

a letter that says I have some questions about a female badkn named Miriam dressed as a man

so many things to do so many things come up it becomes easier to write the poem about calling about the conditions situations possibility

than to leap across the distance of gender politics generation to ask about not knowing how far will it be adjusting mid-flight (why am I so interested?)

the things $\mathrm{i}$ already know: from allan contemporary badkn researcher of the traditional loans me a book jewish music in its historical development tells me about badkns satirical performers at weddings and elsewhere travelling composing singing speaking making fun a female badkn

and a film lecture a yingl mit a yingl hot epes a tam gay \& lesbian subtext in yiddish film and in the films with molly picon cross-dressing is a gag the moral ending resurges underneath \& truly a woman dressed as a man 
some things i don't know: where did Miriam live? when? how did she live? for women to be badkns? dressed as a man a common practice? why was Miriam dressed this way? photographed this way? how would she have been received by others? been interpreted by others? practice her craft? a female badkn

pleased to meet you

those are the questions for when I have the time clear out clutters of ideas for poems stories essays films competing for attention in my brain on my desk sequences of neurons jamming against files of paper screeching to a halt at publication \& other deadlines

for when Ihave the courage to reach across a distance and find maybe likely that the answers negate the excitable theory constructed in my head based on

performing gender lesbian history passing women \& drag

\& the time I went into a vintage store clothes-by-the-pound in san francisco to buy a man's dark suit

what if it's just a game like molly picon or shakespeare's 12th night where order is restored (everyone straight and appropriately paired) and everyone laughs at the end?

some things i want to be true: connection between weddings gender satire subversion roles consciously proudfully performed not circumscribed

this is the film I constructed in my head on paper 
moving too fast for speech \& the fear of never having made a film before

I wanted to show the photograph of Miriam passing in slow grainy motion from hand to hand me putting on the suit in slow grainy motion that Ibought the one that looks just like hers

\& to overlay in voice the answers to my questions moving from the factual to the conceptual \& me talking about seeing that photograph to tell that I had some questions and what they were \& moving too from the factual to the meaning of a dark blue suit on a girl

it was going to be simple a first film has never quite happened maybe it still will

a dark blue suit $i$ wore not in the manner of a cabaret but as a suit $i$ inhabited to the party an office party at the gay \& lesbian newspaper offices a small community for me of bisexuals \& stiletto fags \& mario saying $i$ am a lesbian trapped in a gay man's body as he devoured my porno mag future sex wrinkling the pages a party that i made into a different world wearing a suit and for fun \& magic a plastic cock (a dildo) held hard against my crotch elastic tight in my underpants tenting my dark blue slacks almost made it behind mario to press before he noticed shrieking what are you wearing? transforming an attitude that let me tell shawn get me a glass of red wine then kneel (before me) as my hand steady as though possessed from beyond poured a steady stream red into his mouth look said mario he's submitting to her

pleased to meet you

breaking the spell and shawn sputters we unravel the order not restored

this never happened outside of the man's suit allowing me to take them otherwise too risky to desire with other codes in play 
and until Icancall and read up and know that what I wanted Miriam to be does not have to be that way

that my suit and her suit can be 2 different things for 2 different women across space time \& gender and the constructs of politics sexuality generation performance etc.

that I can remember her clever \& mischievous eyes and her hunched over standing in the mud in a dirt road somewhere probably in Poland

and bestrengthened not to take myeyes off her and know that I am more than an old photograph coming to life

until then these are just words for Miriam

(i finger the folds of my 2nd-hand suit hanging still in my closet)

with thanks to the Tessera collective for the call that inspired David for hanging on 'til it was done the women of Libby Sheier's writers workshop for their comments Ellen's comments and the encouragement from both her and Rozena 